\title{
Industry Market Structure and Banking Performance in Indonesia
}

\author{
Ignatius Roni Setyawan ${ }^{1 *}$ \\ Margarita Ekadjaja' \\ Agustin Ekadjaja \\ ${ }^{1}$ Faculty of Economics and Business, \\ Tarumanagara University, Jl. Tanjung Duren Utara 1, \\ DKI Jakarta, 11470 Indonesia \\ ${ }^{*}$ Corresponding Author
}

DOI: https://doi.org/10.36941/ajis-2022-0056

\begin{abstract}
After the economic crisis, Indonesian banks began to compile the Indonesian Banking Architecture to design the Indonesian banking system. Banks mostly have a motive to increase their market share by increasing the amount of third-party funds and the amount of credit extended, thus changing the character of the banking market structure in Indonesia. This research measures the effect of performance as reflected in the level of bank profitability in relation to the market structure by assuming that these conditions are influenced by internal (Asset Liability Management) and market factors. Bank market concentration is measured by the Herfindahl-Hirschman Index. This research concludes that the Indonesian banking industry has a monopolistic market structure. The effect of bank market concentration, capital ratio, and liquidity ratio are positive and significant on bank performance. Conversely, the credit risk ratio has a negative effect on banking performance.
\end{abstract}

Keywords: capital ratio, liquidity ratio, credit risk ratio, market concentration

\section{Introduction}

In January 2004, Bank Indonesia issued the Indonesian Banking Architecture (API) policy with the aim to help banks to reach economic scale and increase the positivity of the banking system. The growth in several banks led to intense competition and pushed a number of banks out from the market or joining the others. With the increase of total third party funds and credits given by the bank, the bank profitability (Return On Asset) increased.

Research conducted by Mala (2017) and Jumono et al. (2016) show that Indonesia banking industry is an oligopoly market and Return On Asset can influence industrial banking performance. However, Mulyaningsih \& Daly (2012) conclude that banks in Indonesia were in a monopolistic condition during 2001-2009.

Lee (2014) analyzes bank competition and bank profitability variables. This research proves that a higher change in market structure will increase bank profits. Research conducted by Adelopoetal. (2018) and Pinto et al. (2017) show that the dynamics of bank profitability are related to internal and 
external factors of the bank. They conducted the research using the basic logic of the performance implementation structure paradigm and using neoclassical theory that considers and adjusts the market and economic conditions of a country.

According to Kuo (2004), the measurement of bank performance is reflected in the measurement of the level of profitability. According to Ostadi \& Monsef (2014), the measurement indicator commonly used to measure bank profitability is the Return On Asset (ROA).

Research on the impact of external banking activities on bank profitability were also conducted by Pervana et al. (2015) and Bougatef \& Korbi (2018). Pervana et al. (2015) analyze the influence of macroeconomic factors as reflected by the exchange rate on customer behavior as reflected by the deposit interest rate. Pinto et al. (2017) conclude that capital adequacy and financial leverage can increase the company profitability.

According to Gugler \& Peev (2018), in developing countries the role of banks in mobilizing funds is generally more dominant than the role of the capital market. The role of banking in the economy in developing countries like Indonesia is very important. Karim \& Alam (2013) find that the banking industry in Indonesia with its economic movements has a correlation close to one. Ally (2014) finds that the type of bank ownership in Indonesia has a significant effect on bank performance.

Based on these facts, the measurement of bank performance is very necessary, especially for shareholders, creditors, consumers, and the government. The results of the research by Ben Selma Mokni \& Rachdi (2014) show that the use of fundamental analysis can be done to measure performance, which is done by analyzing financial statements using financial ratios.

This research measures the effect of performance as reflected in the level of bank profitability in relation to the market structure in Indonesia, with the assumption that it is influenced by internal conditions (ALMA) and external conditions (market and macroeconomic factors). The orientation of this research is how the market structure of banks in Indonesia is related to the type or profile of ALMA from time to time where the bank must maintain its position at the level of BUKU 1,2,3, and 4 . This research distinguishes from prior research by analyzing the relationship between ALMA and market structure in Indonesia with the following problems limitations: 1) What is the level of concentration or market structure of banks in Indonesia? 2) How is the effect of concentration or market structure of banks in Indonesia on profitability? 3) What are the impacts of CAR, NPL, and LDR on the profitability of banks in Indonesia?

\section{Literature Review and Hypothesis Development}

\subsection{Literature Review}

Neuberger (1998) in Bucevska and Bucevska \& Hadzi Misheva (2017) create an SCP (Structure Conduct Performance) framework that can adapt to the situation of bank characteristics. As an intermediary institution, banks deal with agency problems such as overcoming imperfections in existing information. Another unique benefit of the banking industry is that it is highly regulated and has to follow strong regulations in addition to public policy.]

The relationship between structure, behavior, and performance is mutually sustainable, where the structure of an industry has a correlation with the industry's behavior which in turn will affect the performance of the industry concerned. The variables that affect the market structure include economic scale, market concentration, product differentiation, capital intensity, export, and import market [see Yudaruddin (2014)]. Bikker et al. (2014) state that the level of banking concentration can be measured by the concentration ratio. The concentration ratio can indicate the changes in concentration as a result of the entry of all banks into the market or exit from the market or the merger and exit of all banks from and into the market.

Jacobson and O'Callaghan (1996:53) describe the concentration method, namely CRN or N firm concentration and the Herfindahl-Hirschman Index. The Herfindahl-Hirschman Index (HHI) is the 
most extensive measurement indicator in terms of concentration theory and is often used as a benchmark for evaluating other concentration indices. This guideline implies that the post-merger market does not exceed 0.18 , and the increase in the index from the pre-merger is less than 0.02 , as suggested by Cetorelli and Gambera (2001), with the following formula:

$H H I=\sum_{i=1}^{k} \quad S i^{2}$

$\mathrm{S}_{\mathrm{i}}^{2}$ shows the square of the size of the bank which is measured as market share.

The banking concentration is a bank whose operational activities are more focused on customers or large companies or even small and medium companies. Banking concentration is measured by the Herfindahl-Hirschman Index (HHI), which is the sum of all market shares as mentioned by Fang et al. (2019). Profitability is valued as an intermediary target to achieve the main goal (Artha \& Mulyana, 2018; Salvatore, 2015). Optimal profitability is one of the banking activities in managing bank asset liability (Asset Liability Management = ALMA). Gavurova et al. (2017) use a theoretical framework regarding the factors that affect profitability, concentration market, and other macroeconomics variables. (Ally, 2014) shows that the more centralized the market is, the more likely it is to achieve normal profitability and market efficiency.

\subsection{Hypothesis Development}

Simatele (2015) shows that concentration affects traits. The relationship between profitability and structure is dominantly explained by the structure in the hypothesis. The following is a picture of a research framework that explains the formulation of the hypothesis:

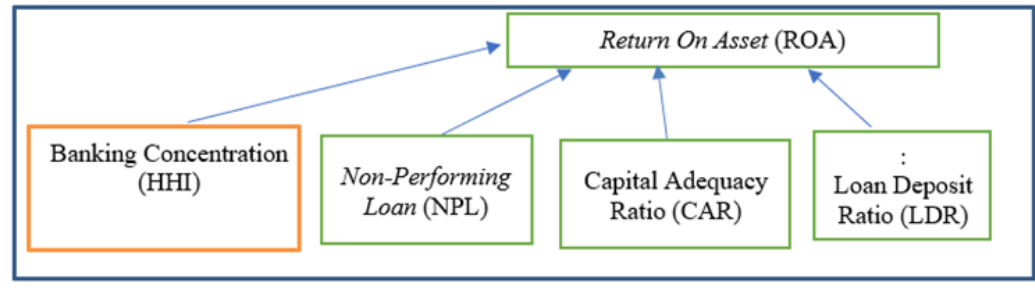

Figure 1: Research Framework

Source: Data Analysis, 2020

Figure 1 describes the formulation of the research hypothesis as follows: According to Ally (2014), the more centralized the market is, the more likely it is to achieve normal profitability and market efficiency. However, it is different from the research conducted by Smirlock (1985) which observes that the relationship between the level of market concentration and the level of bank profitability is not related to banking. Based on the above, Hypothesis 1 and 2 can be formulated as follows:

$\mathrm{H} 1$ : The banking market structure in Indonesia is concentrated in the Herfindahl-Hirschman Index

H2: Herfindahl-Hirschman Index (HHI) has an effect on Return On Asset

Yanuardi et al. (2014) conducted research using the Risk of credit, Capital, and Inflation variables which have a significant positive effect on profitability as measured by ROA. The results of Buchory (2016) show that the Loan to Deposit Ratio (LDR), Net Interest Margin (NIM), and Operating Expense to Operating Income (OE/OI) variables have a positive effect on Return On Assets (ROA). Based on the above, the third hypothesis can be formulated as follows:

H3: Non-Performing Loan, Capital Adequacy Ratio, and Loan Deposit Ratio (LDR) have an effect on Return On Assets. 


\section{Research Method}

This research is categorized as applied research with the aim of applying the results from previous research hypotheses (Etale et al., 2016). The basic idea of making a relationship between profitability with internal factors (the nature and operation of the bank) and external factors (market structure and basic conditions) refers to the SCP theory. The economic model in the research is adapted to the current banking conditions in Indonesia by referring to the concept of Dungey and Gajurel (2015) who tested the SCP theory on commercial banks by using the 8-year time frame panel data regression.

The reason for using the 8-year time frame for this research is because Indonesian banks have different values and measures for each unit with a large number of frequencies throughout the time period according to BUKU 1,2,3, and 4. The sample selection technique uses purposive sampling technique.

The research data is taken from the financial statements of banking companies registered with the Indonesian Financial Services Authority for 8 years. Based on the criteria obtained, there are more than 58 banks that meet the requirements, so the total research data reaches more than 464 observations.

The following is a research equation model: $\mathrm{ROA}_{\mathrm{i}, \mathrm{t}}=\beta_{\mathrm{o}}+\beta_{1} \mathrm{HHI}_{\mathrm{i}, \mathrm{t}}+\beta_{2} \mathrm{NPL}_{\mathrm{i}, \mathrm{t}}+\beta_{3} \mathrm{CAR} \mathrm{R}_{\mathrm{i}, \mathrm{t}}+\beta_{4}$ $\operatorname{LDR}_{i, t}+e_{i, t}$

Table 1: Operational Variable

\begin{tabular}{|c|c|c|c|c|c|}
\hline No & Variable & Definition & Indicator & Measure & Scale \\
\hline \multicolumn{6}{|c|}{ Dependent Variable } \\
\hline 1. & $\begin{array}{l}\text { Public Bank } \\
\text { Profitability }\end{array}$ & $\begin{array}{l}\text { The capability of public bank to } \\
\text { gain profit }\end{array}$ & ROA & $\begin{array}{l}\text { Net income divided by } \\
\text { total assets }\end{array}$ & Ratio \\
\hline \multicolumn{6}{|c|}{ Independent Variable } \\
\hline 1. & \begin{tabular}{|l|} 
Banking Industry \\
Market Concentration
\end{tabular} & $\begin{array}{l}\text { Banks whose operations are } \\
\text { more specialized in large } \\
\text { corporate customers }\end{array}$ & $\begin{array}{l}\text { Herfindahl- } \\
\text { Hirschman Index } \\
(\mathrm{HHI})\end{array}$ & $\begin{array}{l}\text { The square sum of all } \\
\text { market shares }\end{array}$ & Ratio \\
\hline \multirow[t]{3}{*}{2.} & \multirow[t]{3}{*}{ Bank Financial Ratio } & \multirow[t]{3}{*}{$\begin{array}{l}\text { Comparison of bank business } \\
\text { in order to improve bank } \\
\text { performance }\end{array}$} & $\begin{array}{l}\text { NPL (Non - } \\
\text { Performing Loan) }\end{array}$ & $\begin{array}{l}\text { Total non-performing } \\
\text { loans divided by total } \\
\text { loans extended }\end{array}$ & Ratio \\
\hline & & & $\begin{array}{l}\text { CAR (Capital } \\
\text { Adequacy Ratio) }\end{array}$ & $\begin{array}{l}\text { Total bank divided by } \\
\text { total Risk Weighted } \\
\text { Assets }\end{array}$ & Ratio \\
\hline & & & $\begin{array}{l}\text { LDR (Loan } \\
\text { Deposit Ratio) }\end{array}$ & $\begin{array}{l}\text { Total credit divided by } \\
\text { total deposit }\end{array}$ & Rati \\
\hline
\end{tabular}

Source: adapted from Cetorelli and Gambera (2001) and Taswan (2015)

\section{Result and Discussion}

\subsection{Descriptive Statistics Result}

Table 2: Descriptive Statistics

\begin{tabular}{|l|c|c|c|c|c|}
\hline & ROA & HHI & CAR & NPL & LDR \\
\hline Mean & $\mathbf{2 . 2 1 2 4 3 5}$ & 0.099144 & 19.64218 & 1,225776 & 87.67935 \\
\hline Median & $\mathbf{2 . 2 2 5 0 0 0}$ & 0.092550 & 17.57000 & 0,805000 & 86.92000 \\
\hline Maximum & 7.440000 & 0.210560 & 82.50000 & 9,650000 & 251.1000 \\
\hline Minimum & -11.15000 & 0.070070 & 0.180000 & $-3,390000$ & 0.680000 \\
\hline Std. Dev. & 1.850741 & 0.037390 & 8.121614 & 1,310894 & 22.70054 \\
\hline
\end{tabular}




\begin{tabular}{|l|c|c|c|c|c|}
\hline & ROA & HHI & CAR & NPL & LDR \\
\hline Skewness & -1.608692 & $\mathbf{2 . 2 5 8 7 5 5}$ & $\mathbf{2 . 3 5 5 4 1 4}$ & 1,948579 & $\mathbf{2 . 2 0 8 9 6 8}$ \\
\hline Kurtosis & 11.73484 & 6.794435 & $\mathbf{1 4 . 2 0 6 4 7}$ & 10,57995 & $\mathbf{2 1 . 0 5 8 3 0}$ \\
\hline Jarque-Bera & 1675.214 & 672.9089 & $\mathbf{2 8 5 7 . 0 1 8}$ & $\mathbf{1 4 0 4 . 4 4 1}$ & 6681.991 \\
\hline Probability & 0.000000 & 0.000000 & 0.000000 & 0.000000 & 0.000000 \\
\hline Sum & 1026.570 & 46.00293 & 9113.970 & 568.7600 & 40683.22 \\
\hline Sum Sq. Dev. & 1585.886 & 0.647278 & 30539.77 & 795.6389 & 238590.7 \\
\hline Observations & 464 & 464 & 464 & 464 & 464 \\
\hline
\end{tabular}

Source: Data Analysis (2020)

Based on table 2, it is identified that banks in Indonesia have a very healthy banking performance from 2009-2016. This is reflected in the NPL value of 1.225776 which indicates that based on the criteria for determining the risk profile, ratings of banks in Indonesia are very healthy because they are in an NPL position < $2 \%$ (PBI No. 6/23 / DPNP 2004). The NPL variable has a mean value of 1.225776 and a median value of 0.805 with a standard deviation of 1.310894 . The maximum value is 9.65 and the minimum value is -3.39 .

An LDR of 87,67935 indicates that the criteria for banks in Indonesia in terms of the Loan Deposit Ratio (LDR) of these banks are in a fairly healthy criteria, as evidenced by the LDR value of banks in Indonesia which are categorized as quite healthy banks $(85 \%<\mathrm{LDR} \leq 100 \%)$. The LDR variable has a mean value of 87,67935 and a mean value (median) of 86.92 with a standard deviation of 22,70054.

CAR of 19,64218 indicates that banks in Indonesia are in a very healthy position, namely the CAR value of banks in Indonesia $(19,64218)>12 \%$. The CAR variable has a mean value of 19.64218 and a median value of 17.57 with a standard deviation of 8.121614.

Likewise, the ROA value of banks in Indonesia is 2,212435, indicating that the bank is categorized as very healthy, as seen in the ROA of banks in Indonesia $(2,212435)$ which are classified as very healthy banks (ROA $>1.5 \%$ ). The ROA variable has a mean value of 2.212435 and a median value of 2.225000 with a standard deviation of 1.850741 . The HHI variable has a mean value of 0.099144 and a middle value (median) of 0.09255 with a standard deviation of 0.037390 .

\subsection{Model Analysis}

Table 3: Chow Test

\begin{tabular}{|l|c|}
\hline Item & Result \\
\hline Cross-section F & 8.768351 \\
\hline & $\left(0.00{ }^{*}\right)$ \\
\hline Cross-section Chi-square & 374.882415 \\
\hline & $\left(0.000^{*}\right)$ \\
\hline
\end{tabular}

Source: Data analysis (2020)

Table 3 shows the probability that the Chi-square cross-section is o so that the panel data regression model that should be used is the fixed effect model or random effect model. The panel data regression model testing will be continued using the Hausman test.

Table 4: Hausman Test

\begin{tabular}{|l|c|}
\hline Result & Chi-Sq. Statistic \\
\hline Cross-section random & $35.97862\left(\right.$ o.ooo $\left.^{*}\right)$ \\
\hline
\end{tabular}

Source: Data analysis (2020) 
Table 4 shows that the probability of random cross-section is o so that the panel data regression model that should be used is the random effect model.

Table 5: The results of hypothesis testing with panel data regression (ROA as Dependent Variable)

\begin{tabular}{|l|c|c|}
\hline Independent Variable & Coefficient & P-value \\
\hline C & $-5.865324^{* * *}$ & $($ o.oooo $)$ \\
\hline HHI & $70.67678^{* * *}$ & $($ o.oooo $)$ \\
\hline NPL & $-0.210570^{* * *}$ & $(0.0005)$ \\
\hline CAR & 0.009362 & $(0.3915)$ \\
\hline LDR & $0.013056^{* * *}$ & $($ o.ooog) \\
\hline R-squared $=0.629575$ & Note: $^{* * *}$ : significant at $1 \%$ level \\
\hline
\end{tabular}

Source: Data analysis (2020)

From Table 5 above, we can see the regression equation shows the results of multiple linear regression analysis using a fixed effect model. The following regression equation used in this research refers to the results of the multiple linear regression analysis above:

ROA $=-5.865324^{* * *}+70.67678^{* * *} \mathrm{HHI}-0.21057^{* * *} \mathrm{NPL}+0.009362 \mathrm{CAR}+0.013056^{* * *} \mathrm{LDR}$

$\mathrm{HHI}$ has a positive regression coefficient value of 70.67678 . The negative value contained in the regression coefficient indicates that $\mathrm{HHI}$ has a positive effect on ROA. An increase in the value of the $\mathrm{HHI}$ by one unit will result in an increase in the ROA value by 70.67678 .

NPL has a negative regression coefficient value of 0.21057 . The negative value contained in the regression coefficient indicates that NPL has a negative effect on ROA. An increase in the NPL value by one unit will result in a decrease in the ROA value by 0.21057 . Conversely, the ROA value will increase by 0.21057 when the NPL value decreases by one unit.

CAR has a regression coefficient value of 0.009362 . The positive value contained in the regression coefficient shows that CAR has a positive effect on ROA. An increase in the CAR value by one unit will result in an increase in the ROA value by 0.009362 .

LDR has a regression coefficient value of 0.013056 . The positive value contained in the regression coefficient indicates that LDR has a positive effect on ROA. An increase in the LDR value by one unit will cause the ROA value to increase by 0.013056 .

The simultaneous test result ( $\mathrm{F}$ test) is a test conducted to determine whether all independent variables are simultaneously able to influence the dependent variable used in the study. The probability value (F-statistic) is the value that is considered in carrying out the test simultaneously ( $\mathrm{F}$ test). This study uses a confidence level of $95 \%$. The probability value (F-statistic) < 0.05 indicates that Ho is rejected.

The regression coefficient shows a probability (F-statistic) value of o.oooooo. The probability value (F-statistic) < 0.05 indicates that Ho is accepted so that HHI, NPL, and LDR are simultaneously influencing ROA. The probability value is the value that is considered in doing the partial test (t-test). This study uses a confidence level of $95 \%$. A probability value < 0.05 indicates that Ho is accepted.

The regression coefficient shows that HHI, NPL, and LDR have a probability value $<0.05$, indicating that Ho is accepted so that HHI, NPL, and LDR are partially able to influence ROA. The regression coefficient shows that CAR has a probability value of 0.3915 . A probability value $>0.05$ indicates that Ho is rejected so that CAR is partially unable to influence ROA.

The R-squared value indicates that the independent variables in this study, namely HHI, NPL, CAR, and LDR are able to explain the dependent variable in this study, namely ROA of 0.629575 or $62.96 \%$. The dependent variable used in this study, namely ROA, is also influenced by other factors besides HHI, NPL, LDR, and CAR of 0.3704 or $37.04 \%$. 


\subsection{Discussion}

The orientation of this research is to know the market structure of the banking industry in Indonesia related to the type or profile of the Asset Liability Management (ALMA) from time to time where the bank must maintain its position at the level of BUKU 1,2,3, and 4 . The variables in this study consist of: dependent variable, namely profitability of domestic banks measured by Return on Asset (ROA) and independent variables: Non-Performing Loan (NPL), Capital Adequacy Ratio (CAR), Loan to Deposit Ratio (LDR), and banking industry market concentration as measured by the HerfindahlHirschman Index (HHI).

The descriptive statistics in Table 2 shows that a bank's LDR is 87,67935 , indicating that the bank is directed towards a monopolistic type, where the bank is a bank that has a low market share in terms of the amount of third party funds. For the amount of credit disbursed, it can be seen in the Loan Deposit Ratio (LDR). If the value is $>100 \%$, then the bank is classified as the oligopoly type Mala (2017). A bank like this will continue to strive to increase the Herfindahl-Hirschman Index (HHI) value so that it remains the leader in its industry. Monopolistic banks will maximize the value of ROA by increasing CAR, tightening Non-Performing Loans (NPL), and increasing LDR Mala (2017).

Apart from the banks being able to maintain their uniqueness or competitive advantage in order to remain as the leader in the industry, the other banks can mimic the strategy or follow the large banks to also maintain their position in the market. [see the research conducted by Wen and Tickoo (2020) and Setyawan \& Ramli (2016)].

Table 6: Research Summary

\begin{tabular}{|l|c|c|l|l|}
\hline Variable & Symbol & Prob & Sign & Support \\
\hline Non-Performing Loan & NPL & 0.0005 & Positive Significant & Ally (2014) \& Smirlock (2015) \\
\hline Capital Adequacy Ratio & CAR & 0.3915 & Positive Insignificant & - \\
\hline Loan Deposit Ratio & LDR & 0.0009 & Negative Significant & Buchori (2016) \\
\hline Market Concentration & HHI & 0.0000 & Positive Significant & Buchori (2016) \\
\hline
\end{tabular}

Source: Data Analysis (2020)

Based on Table 6 above, it is identified that the market concentration (HHI), credit ratio (NPL), and bank capital (CAR) variables have a positive effect on bank performance (ROA). This is evidenced by the probability that HHI, NPL, and CAR are smaller than the significance level $(<0.05)$. On the other hand, the effect of the non-performing credit variable (LDR) on bank performance (ROA) is in the opposite direction (negative), meaning that the higher the Loan Deposit Ratio (LDR) causes a decrease in bank performance as reflected in the ratio of profit to bank assets (ROA).

\section{Conclusion}

Based on the results of the research, it can be concluded that banks in Indonesia have a monopolistic banking structure. This is evidenced by the results of the research showing that the banking market structure in Indonesia is concentrated and is related to banking performance. The results also show that Capital Adequacy Ratio (CAR) and Loan Deposit Ratio (LDR) have a positive relationship with banking performance (ROA), which means that banks must increase their Capital Adequacy Ratio and provide credit to increase their banking performance. On the other hand, the Non-Performing Loan (NPL) variable has an opposite (negative) relationship, which means that banks must reduce their Non-Performing Loan if they want to improve their bank performance.

The managerial implication of this research is that market concentration can be used to measure the increase in bank performance. However, the bank Capital Adequacy Ratio (CAR) 
variable does not have a significant effect on improving banking performance in Indonesia. To improve further research, the variable part of the bank Capital Adequacy Ratio (CAR) should be used as a separate research topic for further research in measuring bank performance.

\section{Acknowledgement}

The authors would like to thank the Tarumanagara University Research and Community Service Institute (LPPM UNTAR) which has provided funding assistance for our study with the research agreement letter No. 1786-Int-kLPPM/UNTAR/X/2019.

\section{References}

Adelopo, I., Lloydking, R., \& Tauringana, V. (2018). Determinants of bank profitability before, during, and after the financial crisis. International journal of managerial finance, 14(4). 378-398. https://doi.org/10.1108/IJMF-072017-0148

Ally, Zawadi. (2014). Determinants of banks' profitability in a developing economy: empirical evidence from Tanzania. European journal of business and management, 6(31). 363-376. https://www.iiste.org/Journals/ index.php/EJBM/article/view/16568.

Artha, I. W. B., \& Mulyana, B. (2018). The effect of internal and external factors of companies on profitability and its implications on stock price index of state-owned banks. The Economics and Finance Letters, 5(2).58-71 https://doi.org/10.18488/journal.29.2018.52.58.71.

Ben Selma Mokni, R., \& Rachdi, H. (2014). Assessing the bank profitability in the MENA region. International journal of Islamic and middle eastern finance and management, 7(3).305-332. https://doi.org/10.1108/imefm03-2013-0031

Bikker, J. A., van Leuvensteijn, M., Kok, C., \& Van Rixtel, A. (2014). "Impact of bank competition on the interest rate pass-through in the euro area". Working paper series. http://www.ecb.europa.eu or from the social science research network electronic library at http://ssrn.com/abstract_id=1105385.

Bougatef, K., \& Korbi, F. (2018). The determinants of intermediation margins in Islamic and conventional banks. Managerial Finance, 44(6).704-721. https://doi.org/10.1108/MF-11-2016-0327.

Bucevska, V., \& Hadzi Misheva, B. (2017). The determinants of profitability in the banking industry: Empirical research on selected Balkan Countries. Eastern European economics,oo.1-22 https://doi.org/10.108o/00128775.2016.1260473

Buchory, H.A. (2014). Analysis of the effect of capital, credit risk and profitability on the implementation of a banking intermediation function (Study on Regional Development Bank All Over Indonesia Year 2012). International journal of business, economics and law, 4(1), 133-144.

Dungey, Mardi., \& Gajurel, Dinesh. (2015). Contagion and banking crisis - International evidence for 2007-2009. Journal of Banking and Finance, 6o(c), 271-283. https://doi.org/10.1016/j.jbankfin.2015.08.007.

Etale, Lyndon. M., Bingilar, Paymaster. F., \& Ifurueze, Meshack. S. (2016). Market share and profitability relationship: A study of the banking sector in Nigeria. International journal of business, economics and management, conscientia beam, 3(8), 103-112.https://doi.org/10.18488/journal.62/2016.3.8/62.8.103.112.

Fang, J., Lau, C. K. M., Lu, Z., Tan, Y., \& Zhang, H. (2019). Bank performance in China: A Perspective from bank efficiency, risk-taking and market competition. Pacific basin finance journal, 56, 290-309. https://doi.org/10.1016/j.pacfin.2019.06.011.

Gavurova, B., Kocisova, K., \& Kotaskova, A. (2017). The structure - Conduct - Performance paradigm in the European union banking. Economics and Sociology, 10(4),99-112. https://doi.org/10.14254/2071-789X.2017/10-4/8.

Gugler, K., \& Peev, E. (2018). The persistence of profits in banking: an international comparison. Applied Economics, 5o(55), 5996-60o9. https://doi.org/10.108o/ooo36846.2018.1489111.

Jumono, Sapto., Achsani, N. A., Hakim, D. B., \& Fidaus, M. (2016). The effect of loan market concentration on banking rentability: A study of Indonesian commercial banking, dynamics panel data regression approach. International Journal of Economics and Financial Issues, 6(1),207-213.

Karim, R. Al, \& Alam, T. (2013). An evaluation of financial performance of private commercial banks in Bangladesh: Ratio analysis. Journal of business studies quarterly,5(2),65-77.

Kasmir. (2014). Bank dan lembaga keuangan lainnya. Jakarta: PT Raja Grafindo Persada.

Kuo, C.-C. (2004). Research on impacts of team leadership on team effectiveness. Journal of American academy of business, 1(1),1-22. 
Lee, C. C., Hsieh, M. F., \& Yang, S. J. (2014). The relationship between revenue diversification and bank performance: Do financial structures and financial reforms matter . Japan and the World Economy, 29, 1835. https://doi.org/10.1016/j.japwor.2013.11.002.

Mala, C. M. F. (2017). The prospect of dual unit banking system in Indonesian regional banking. Account and financial management journal, 2(1), 592-599. https://doi.org/10.18535/afmj/v2i1.05.

Mulyaningsih, T., \& Daly, A. (2012). Competitive conditions in banking industry : An empirical analysis of the consolidation, competition, and concentration in the Indonesia banking industry between 2001 and 2009.Buletin ekonomi moneter dan perbankan, 14(2), 141-175. https://doi.org/10.21098/bemp.v14i2.83.

Neuberger, D. (1998). Industrial organization of banking: A review. International journal of the economics of business, 5, 97-118. https://doi.org/10.1080/13571519884594.

Ostadi, Hosin., \& Monsef, N. (2014). Assessing the impact of bank concentration and liquidity of Refah Bank branches on profitability during the period 1383-190. International journal of human resource studies, 4 (1), 248-258. https://doi.org/10.5296/ijhrs.v4i1.5644.

Pervana, M., Pelivan, I., \& Arnerić, J. (2015). Profit persistence and determinants of bank profitability in croatia. Economic Research-Ekonomska Istrazivanja, 28(1) , 284-298.https://doi.org/10.1080/1331677X.2015.1041778.

Pinto, P., Thonse Hawaldar, I., Quadras, J. M., \& Joseph, N. R. (2017). Capital structure and financial performance of banks. International journal of applied business and economic research, 15(23), 303-312.

Setyawan, I.R. \& Ramli, I. (2016), "Herding Behavior in the Indonesia Stock Exchange: The Roles and Contributions of Foreign Investors During the Period 2006 to 2011" , Jurnal Pengurusan Vol. 46, 125-135

Simatele, M. (2015). "Market structure and competition in the South African banking sector". Procedia economics and finance,825-835.https://doi.org/10.1016/s2212-5671(15)01332-5

Smirlock, M. (1985). Evidence on the (Non) Relationship between Concentration and Profitability in Banking. Journal of Money, Credit and Banking,17(1). 69-83.https://doi.org/10.2307/1992507.

Yanuardi, A., Hadiwidjojo, D., \& Sumiati. (2014). Faktor determinan atas profitabilitas perbankan yang listing di Bursa Efek Indonesia. Jurnal Akuntansi Multiparadigma, 5(2), 202-218. https://doi.org/10.18202/jamal.2014.08.5014.

Taswan, T., Tandelilin, E., Husnan, S., \& Hanafi, M. (2015). Bank risk and market discipline. Journal of Indonesian economy and business, 27(3), 303-314.https://doi.org/10.22146/jieb.6236.

Wen, Y. \& Tikoo, S. (2020), Corporate Strategy Uniqueness, Analyst Herding and Financing Constraint, Strategic Organization, 1-21, https://doi.org/10.1177/1476127020928013.

Yanuardi, A., Hadiwidjojo, D., \& Sumiati. (2014). Faktor determinan atas profitabilitas perbankan yang listing di Bursa Efek Indonesia. Jurnal akuntansi multiparadigma. 5(2),170-274.https://doi.org/10.18202/jamal.2014.08.5014.

Yudaruddin, Rizky.(2014).Dampak tingkat konsentrasi terhadap stabilitas perbankan di Indonesia Tahun 20032013.Jurnal keuangan dan perbankan,18(2), 278-286. 